Katarzyna Wrońska (iD) http:/orcid.org/0000-0001-6617-4415

Uniwersytet Jagielloński

\title{
Education and freedom. An essay on Józef Tischner's pedagogical thought ${ }^{1}$
}

\author{
Abstract \\ Wychowanie a wolność. Próba wglądu w myślenie pedagogiczne \\ Józefa Tischnera
}

Tekst pisany z perspektywy pedagogiki filozoficznej jest próbą wglądu w myślenie pedagogiczne jednego z filozofów wolności - Józefa Tischnera. Autorka stawia przed sobą zadanie wydobycia i odczytania ze źródłowych tekstów i wypowiedzi Tischnera znaczeń i sensu, jakie nadaje on edukacji. Ma to służyć dwóm celom. Pierwszy z nich odpowiada na zapotrzebowanie pedagogiki, która szuka filozoficznych uzasadnień dla podejmowanej działalności pedagogicznej. Drugi cel ściślej wiąże się z zapotrzebowaniem filozofii; chodzi o sprawdzenie, w jaki sposób refleksja pedagogiczna wkomponowuje się w koncepcję filozoficzną autora Myślenia według wartości oraz co do niej wnosi. Uściślając ten drugi cel, autorka chce szukać odpowiedzi na pytanie: czy pedagogia Tischnera jest konsekwentną aplikacją jego filozofii wolności, czy może tę filozofię poszerza?

Key words: education, freedom, totalistic pedagogy, entrustment

Słowa kluczowe: edukacja, wolność, pedagogika totalistyczna, zawierzenie

\section{Introduction}

It is no easy feat to read into the pedagogical thought of Józef Tischner. The work of this philosopher is quite vast and only in some instances applies di-

1 The first version of paper in Polish, see: K. Wrońska (2018). Wychowanie a wolność. Próba wglądu w myślenie pedagogiczne Józefa Tischnera. “Paedagogia Christiana”, 1 (41), p. 97-115. 
rectly to matters of education. There are, however, a few larger studies devoted to understanding and interpreting the pedagogical attitudes of Tischner as they relate to his philosophy (Wajsprych, 2011), or that are derived directly from it (Walczak, 2007). This task is therefore feasible. The proposal to link his pedagogical thought with the subject of treading the path from totalitarianism to freedom is a convenient opportunity to take part in the discussion, joining a group of researchers interested in Tischner's thought. In writing this text from the perspective of philosophy of education, the author has set herself the task of extracting and reading from source texts to find within the words of Tischner - as a philosopher of freedom - the meanings and sense that he assigns to education. The aim of this work is twofold. The first is connected to an interest in pedagogics and the search for philosophical justifications for engaging in pedagogical work. The second relates more closely to the potential need of philosophy to discern how pedagogical reflection fits in and integrates with the philosophical concept of the author of Myślenie wedtug wartości [Thinking in Values] and what it contributes to that concept. To clarify this second aim, is Tischner's pedagogy a consistent application of his philosophy of freedom or is this philosophy perhaps expanded upon and supplemented by the inclusion of an aspect that is invisible from the perspective of the philosophy itself, which is only illuminated once a pedagogical perspective is added to it?

Juxtaposing the philosophical and often very abstract thought of Tischner with his pedagogical attitudes and reflections, so tangible and close to the practice of life, might turn out to be interesting research with uncertain conclusions. The author has deliberately resigned from formulating hypotheses because it better reflects her initial attitude - a willingness to better understand the philosophical nature of pedagogical thought and pedagogical dimension of Tischner's philosophical thought. This kind of analysis - when one does not abandon the field of philosophical considerations and sticks resolutely to education, and hence the domain of pedagogics, is the one I propose to apply here. This will be made possible by Józef Tischner himself, who often assumed such a dual role, both in life and in his writings, as a philosopher and teacher. The testimonies and remembrances that I collected while visiting Łopuszna, a place to which he was particularly connected and which has retained many souvenirs and traces of his presence among the local people, will also provide assistance. It was a place that influenced him and, conversely, also one that seems to cultivate something from his formulated practical philosophy of life. Would Tischner the philosopher and teacher have existed without these places? To what extent are these descriptions of reality interrelated? A cursory look at Tischner's texts allows us to conclude that we are not dealing with a private pedagogy related by a philosopher, but rather a philosophy of education. 
To make a convincing argument on this point, I propose an analysis of the issue as follows.

First, I will try to distil the threads throughout Tischner's works that concern education that cannot be found in his philosophy. Also useful in this respect will be primarily memories and interviews on pedagogical practices taking place in the family, school and church that are available in published texts as well as collected in his family village of Łopuszna, which has retained many souvenirs connected with his life and work (e.g. from "Tischnerówka", the House of Memorial for rev. Professor Józef Tischner). Then I will proceed to a discussion of key texts that embody his pedagogical thought and in which we find a description and definition of the concept of e d u c a t i o n, a description of its essence and opposites in the forms of pseudo-education (counterfeit education), as well as his relationship to $\mathrm{te}$ a $\mathrm{c} \mathrm{h}$ i $\mathrm{n}$ g. Tischner himself admitted that the foundation of every pedagogical theory and practice was some concept of the human being (Tischner, 1966, p. 1334). It is clear what an enormous source of inspiration philosophy has been for pedagogics, including for the philosophy of the author of Spór o istnienie człowieka [The Controversy Over the Existence of Man]. The work that follows, however,adopts a different thrust of analysis. Through insight into pedagogical thinking, I want to use this approach to paint a wider philosophical background within which educational experience is inscribed. This approach is determined by the question posed here about what Tischner's pedagogical thinking brings to his philosophy. It may turn out that insights into pedagogical attitudes will bring greater nuances to some of his philosophical concepts - thanks to their connection with pedagogical experience. Or perhaps pedagogical practice allowed Tischner to reveal some of his philosophical beliefs?

This is therefore a preview of the next step, in which I will interpret Tischner's pedagogy in conjunction with his philosophy. I will pay particular attention here to $\mathrm{fr}$ e e d o m, as a fixed point in Tischner's thinking. Thus, it is impossible to overlook the place of freedom within the area of education. And therefore education in relation to freedom, and vice versa, freedom to education. Combined, they raise the question: to what extent is this a concept of education within freedom and to what extent education into freedom? Or perhaps it is both? How much of his interest in freedom is revealed in his pedagogical beliefs? How much better will freedom itself be understood in conjunction with education and does not pedagogical thinking contribute something to his understanding of freedom? The answer to the last question will be connected to the last part of the text, i.e. a summary of the analysis. If I am able to present Tischner's phenomenology of education, I will seek to reach a point in all these 
considerations by attempting to show the contribution of Tischner's pedagogical thinking to his philosophy of freedom.

\section{Dialogues about education against the background of the Turbacz landscape}

"The world is upside down. It's not good, but I ain't saying it's so terribly bad" this inscription appears in front of the renovated school in Łopuszna. These are Tischner's words - a student of the school, as the caption reads. Both of Tischner's parents were connected with the school in Łopuszna almost from the very beginning. In 1932, Józef Tischner's father became its principal, remaining in that function until 1970, while his mother Weronika was a teacher in the school. The Tischner family lived in the school building, which undoubtedly had an influence on their son, something he addresses further in a discussion within the book Przekonać Pana Boga [To Convince God]. Aside from a home environment steeped in education, his childhood and upbringing was overshadowed by mountains. "Only after many years of hiking and being in the mountains - he reflects in a conversation with Anna Karon-Ostrowska presented in the book Spotkanie [Meeting] - was a kind of philosophy of space born within me. I realised that the idea of a human being's freedom is expressed in space. This thought can be expressed simply: whatever your space, therein is also your freedom" (Tischner, 2008, p. 15-16). After years in an academic setting, he built - on the road to Turbacz - a chalet, where he could return "to his roots, to the landscapes of childhood and first and foremost to the people among whom he grew up. There, he was - writes Wojciech Bonowicz - in every way, at home" (Bonowicz, 2001, p. 281). The mountainous space where he lived and was raised, before he developed his philosophy, would cocreate his fundamental landscape.

Thinking can never escape the boundaries of the landscape a human being carries behind his eyelids. It comes from the home in which a person's soul develops and the past that puts forward images of its heroes. In this way, a human being develops (Bonowicz, 2001, p. 280).

My fundamental landscape comes from the mountains and in small part from the murmur of the Dunajec... However, my religious horizon originates in the wooden churches in the midst of which I grew up - from the church in Jurgów, from the church in Łopuszna ${ }^{2}$.

2 This quote was taken from one of the commemorative plaques at the Parish Church in Łopuszna. 
Against this scenery of home and mountains, another place should be distinguished on the topic of an encounter with another human being. On the surface, it seems, said Tischner:

To be an accidental event: there is no way to know when, where or why... But when it happens, it turns out to be the culmination of the past of the individuals who meet. In that moment, it becomes apparent how significant what these people have lived is when they are face to face (Tischner, 2006, p. 13).

A meeting is the deepest and richest of experiences that a person can have in their life. Whoever has never encountered another human being can truly be said to have wasted their life ${ }^{3}$.

A resident of Łopuszna and friend of Tischner's, Wawrzyniec Kuchta, described him as "the right hand of man" and Wojciech Bonowicz added that although he valued the quiet of the chalet where he worked when returning to Łopuszna, he valued even more "the conversations with neighbours and friends from school whom he met on the way to church, at the bus stop or who came to sit with him in the clearing" (Bonowicz, 2001, p. 281).

Let us complete this landscape with a scene from the road to Turbacz from the first Sunday of August 1981 when, ascending with other residents of Łopuszna, Tischner stopped at the Rusnakowa Clearing to say holy mass. On this occasion, he spoke a few words about freedom and holy sites.

My beloved, when one is here, the meaning of the word 'liberty' becomes clear. Liberty is not the same thing as wantonness. Wantonness destroys, wantonness tramples. It cares not: grass, not grass, wheat, not wheat... Wantonness destroys. Liberty is wise. Liberty understands how to care for a homestead, how to farm the land. The forest ensures that the forest will endure. And that liberty brings out the best in a human being (Bonowicz, 2001 p. 344).

Pursuing his reflections on freedom while standing in the Rusnakowa Clearing, rev. Tischner emphasised the significance of a place, which imbues a person with its holiness.

A holy place is a place where a person tries to be their best. It varies - there are different places around the world. There are places that make a person worse and those that make a person better. A holy place is a place where a person finds the best in themselves and wants to maintain it ${ }^{4}$.

These selected quotes of Tischner, some of which I collected in Łopuszna as I followed in the footsteps of the philosopher, can clearly be interpreted as a pedagogical message. They include instructions for how to live, what to guard

\footnotetext{
3 Another quote taken from this place.

4 Yet another quote from this place.
} 
against, what to respect, how to act so that life is not wasted but given meaning, how to take responsibility for and shape one's life.

\section{Recognising uniqueness, or conversations about education}

In turn, wanting to pull from Tischner's rich collection of texts and words those explicitly devoted to education, it is worth beginning with a chronological snapshot from one of last conversations involving Tischner, with Dorota Zańko and Jarosław Gowin in 1999, published in Przekonać Pana Boga. It was a statement planned by the editors; it is impossible to find an original philosophical construction focused on matters of education, but the text does provide many valuable pedagogical considerations. Since the conversation took place more than 30 years after the writing of his two initial pedagogical texts, $Z$ problematyki wychowania chrześcijańskiego [On Issues of Christian Education] and $Z$ problematyki nauczania [On Issues of Teaching], and almost 20 years after comments on education during the Solidarity period within the The Spirit of Solidarity (to which I will return later), his words are based on far-reaching experience and much reflection. In this conversation, Tischner reveals fragments from his family life and upbringing, describes his childhood and the place where he grew up, his school days when he was educated; he speaks about the influence that his parents, teachers, pastors and peers had on him. It is very valuable biographical knowledge, but also provides insight into his views on education, which he also comments on.

Tischner has a personal appreciation for the fact that he was raised to be responsible, that there were rules to follow in his home, as well as the fact that knowledge and books were highly prized and available. On the other hand, the care with which the child's perspective is considered in the description of education is striking, and consequently, the recognition of his individuality and uniqueness, consideration of his needs and predispositions, permission for the child to be who they are. Tischner is convinced that a child has an inborn sense of justice and dignity, the desire for recognition and respect. That a child expresses the need for independence and freedom. Therefore, this individuality should be valued, in other words recognition and the experience of parental love, combined with facing challenges that require discipline and dedication. They should be taught "the ability to anticipate and think, to see the consequences of their actions" (Tischner, 1999, p. 138), to learn prudence by drawing on self-reliance. Tischner also underlines the significance of fostering multilateralism, or "the ability to think and look at each issue from many sides" 
(Tischner, 1999, p. 134), which protects against, e.g. the cruelty from which children are not exempt. As he puts it, nature needs "intelligent help", which in shaping a child's character means "not breaking but patiently nurturing, referring to what is good in the child" (Tischner, 1999, p. 133).

Tischner directs these pedagogical instructions to parents as the first caregivers and mentors; in turn, from schools he has slightly different expectations. He emphasises that "the first task of a school is to teach, not to raise [a child]", that in school "[a child] is brought up through learning" (Tischner, 1999, p. 145). But learning, as has already been mentioned, Tischner understood not so much as a duty, but as time to develop oneself. As a result, a teacher's role as a pedagogue was first and foremost "to teach an objective and disinterested approach to the subject" (Tischner, 1999, p. 145). Interestingly, much like in the case of upbringing within the family, in describing school he again adopts the child's perspective, whose first approach to the world is objectivity and disinterestedness. Therefore the point is not to lose this attitude, but to build on it and inspire interest in a given discipline of knowledge, its achievements, creators and important figures. In his way, he wants the teacher to be able to build a student's personality by first and foremost being responsible to the student (not the headmaster or parents). As a result, greater significance in pedagogical conduct is assigned to a good teacher rather than to a good pedagogue. Consequently, he believes that the axiological foundation of school and the teaching programme upon which it is based should be based on human rights, civic virtues, self-government and respect for the human being as a creator of culture. In this he sees a way of dealing with nationalism as a faulty teaching programme acquired in school, which makes Polishness an absolute concept. In contrast, Tischner points to humanity as an inviolable value, to which Polishness is subordinated: "Polishness is the road to humanity and not the other way around" (Tischner, 1999, p. 145).

Other aspects of his pedagogical thinking reveals a fragment of conversation dedicated to religious education and, more broadly, to the Catholic Church. In this area, Tischner has a wealth of experience to draw upon, firstly his own seminary formation and later as a lecturer, a priest, giving homilies for almost all social groups, including pre-schoolers. It is a reflection clearly marked by the initial thoughts that he laid out in his basic pedagogical texts years before. Here, I would like to underline a few threads of this conversation. Tischner does not change his convention of speech, and so in response to the question of how to build a child's relationship with the church community, how to introduce a child to the world of faith and familiarise a child with the liturgy, he answers that the primary objective of religious education is "initiation into the Gospel", which "allows us to develop an awareness of human 
values", according to the words: "You are worth more than many sparrows" (Tischner, 1999, p. 157). The objective is to involve children in the liturgy, to ensure they are heard, feel needed and at home in the church and, at the same time, that they have the feeling they are participating in the symbolism and secrets of faith. The transmission of faith extends beyond the priest's abilities, but building a relationship of trust remains. "The theme of education must become the idea of liberation". This means that freedom in conjunction with the true Gospel - Tischner believes - represents a gradual emergence from various enslavements and can be likened to "a plant that slowly emerges from the ground, flowers and bears fruit" (Tischner, 1999, p. 161). In a religious dimension, an apprentice placing his or her trust in a mentor is also the path to building a relationship with God as a point of reference upon which an apprentice can rely (Tischner, 1984, p. 69; Tischner, 1999, p. 165). This trust cannot be violated. A mentor who violates trust is a poor mentor in two ways, as a person and as one in whom God was supposed to be present (Tischner, 1999, p. 166, see also Filek, 2001, p. 107-108, 119-120). The path to God leads through encounters with our fellow human beings (Wrońska, 2010, p. 181-183).

To summarise this section presenting Tischner's pedagogical views, strongly connected with practice or even solicited by questions of concrete teaching advice and suggestions, I would point to the deeply humanistic anthropological approach that is distinctly in the foreground of their author. This keeps the child, the apprentice and student whose growth and recognition of uniqueness must be secured by the actors in his or her life and education, or the family, school and church, permanently in the centre of the pedagogical stage. In an interview, Tischner himself stated that he first felt like a philosopher and then like a priest, with humanity dominating both distinctions ${ }^{5}$. Moving on to the philosophical texts dedicated to education, Tischner delves into the topic with questions about the essence of these processes. The anthropological foundation remains, but is expanded to include an axiological dimension, one which includes ethical considerations.

5 Based on the audiovisual material accessible in "Tischnerówka", the House of Memorial for prof. Józef Tischner in Łopuszna. 


\section{Questions about the essence of education - an introduction to the phenomenology of education}

One of these first deeper philosophical fragments on education can be found in the text $Z$ problematyki nauczania published in 1968. It mentions two functions that a teacher should perform, namely teaching and educating. In this text, the presentation of education against the background of or in conjunction with teaching is visible. Two years earlier, a text devoted explicitly to education, $Z$ problematyki wychowania chrześcijańskiego, Tischner again wrote from a comparative perspective, this time juxtaposing education with pseudo-education. The third fragment on upbringing is a short "philosophical commentary" - as he called it - written "on the move", made alongside several others dedicate to issues such as community, work, science, democracy, family and the fatherland, inspired by the events of 1980 and the emerging Solidarity movement in the The Spirit of Solidarity collection. Here, also, the author draws upon methods of presenting education not directly - as he puts it - from the perspective of an illusion of education.

These three fragments again have something in common, much like within the earlier anthropological concept of the pedagogical stage. Here, education is described as a circuitous route, as if in a distorting mirror. We can assume that in this way Tischner - starting from a caricature of education - wants to peel back the outer shell to find the essence of education, to reach the nature it should have and which it does not. In the first, he is able to show this normativity of education in the light of the concept of truth, in the second from the perspective of Christian principles and in the third within the context of public affairs requiring ethical illumination, justification and valuation, which are collectively called the The Spirit of Solidarity. And if so, it may indicate the appearance in this place of constant features in Tischner's philosophy. This is clearly described in the text Myślenie według wartości. The author argues that our thinking first reveals its level of agathology, or disagreement with something, and only later adds in a level of axiology, or plotting out what should be (Tischner, 2002, p. 483-491). If this is transposed to his philosophical reflections on education - at an agathological level, Tischner describes pseudo-education - what education should not be, how it presents and arouses criticism and discord.

At a later stage - on an axiological level - Tischner lays out a concept of the essence of education and the need for the particular values thanks to which education takes place, such as freedom, dignity and truth. In connection with these values, education itself reveals its nature of preference: it is about something, something important, and it is about someone. Where education 
is linked to values, Tischner writes either directly about the essence of education, or about education in relation to freedom through freedom, to truth through truth... and so on. A case could be made that in this way - not directly - but in the context of values - he is also able to reveal the meaning of education. He admitted as much when he wrote that if one thinks about education, this also touches upon issues of values. That is because:

In education a choice is made according to the adopted hierarchy of values or the personal qualities of the pupil who intends to develop, or of the society in which the child is intended to assimilate (...) it is the act of inoculating a particular hierarchy of ethical values. Without axiology there is no education, although education certainly does not end at axiology (Tischner, 1968, p. 912).

What descriptions of education do we find in these three texts? In the first, education appears almost as the other side of teaching. It is very valuable that Tischner is able to show teaching and education as an integral whole, for which the teacher is responsible. Pedagogical function "is a consequence of the connection between him [teacher - emphasis K.W.] and a second person in the process of internal maturation, growth" (Tischner, 1968, p. 903). However, education itself, as he puts it, "rests on transmitting students certain values, ethical values in particular, as well as the ability to make decisions in accordance with them" (Tischner, 1968, p. 904). A few pages later he writes in a similar vein:

Education rests first and foremost on instilling an authentic hierarchy of values into the pupils so that he considers higher values higher, and lower values as lower. It also involves awakening within the pupil a special sensitivity to universal values, i.e. those that every human being shares. The more detailed the value is, the smaller the scope of the pedagogue. In the case of values such as love for a specific person, or a commitment to, for example painting, a spiritual calling the pedagogue should first and foremost remain silent. The choice will be made by the pupil alone (Tischner, 1968, p. 912).

A few paragraphs later, he points to other situations in which a pedagogue should keep silent. They are connected with the calling to be a teacher, to live according to truth and preach the scientific truth first. "When the teacher is silent - he says - the pedagogue must stop working" (Tischner, 1968, p. 912). Here, it is worth emphasising that despite Tischner's distinction concerning the position of a teacher, the pedagogue is always present in this situation. As far as a teacher is obliged to first pursue truth, the pedagogue's task is to find the right moment to transmit certain truths so that they bear fruit and are well understood (Tischner, 1968, p. 913).

The text $Z$ problematyki wychowania chrześcijańskiego, aside from a reminder of Christian principles that should form the basis of Christian pedagogy, 
provides a description of three forms of pseudo-education: pedagogical mechanism, legalism and totalism. Each is a presentation of education in a distorted mirror. Tischner the priest assesses the pedagogical practice with which he came into contact in his own priestly milieu. Reading, for example, his homilies for pre-schoolers provides us with information on what kind of pedagogue he was in fulfilling his priestly duties. During a mass for children, Tischner did not simply give a homily, but had a conversation with the children concerning, e.g. forgiveness or friendship, during which certain children, addressed by the priest by name, spoke up, brought their teddy bears to mass, felt at home in the Church of Saint Mark, and were simultaneously introduced into mysteries of the Eucharist (Tischner, 2010, p. 22-31, 52-61). Returning to the caricature of education, at the foundation of every pseudos, Tischner believed there was a fear of freedom, the source of "all totalism" (Tischner, 1966, p. 1338). This is his expression for the form of education aimed at inculcating good habits in students (pedagogical mechanism), or shaping obedience to the law (pedagogical legalism), or setting up the pedagogue as a person worthy of imitation (pedagogical totalism). For Tischner, all of these situations expose an illusion, insincerity and claims which, completely unjustified, are laced with an undertone of unbelief in human freedom. "Education presupposes freedom" (Tischner, 1984, p. 68), as he writes in The Spirit of Solidarity and with it the risk that pedagogical outcomes are uncertain (Tischner, 1966, p. 1340). Pedagogical totalism emphasises certainty - the power of habits trained into the students, obedience to norms and the authority of the teacher, a teacher who defends his role as a model worthy of imitation. Tischner sees parallels between a totalist teacher-pedagogue and a totalitarian government.

\section{Education to freedom through freedom}

What does that mean? That at the level of agathology, understood as how education is but should not be, reveals what education should be like. A lack of freedom in its various manifestations within the sphere of education: mechanism, legalism and totalism exposes his proposed, preferred form as education to freedom. But it is accomplished through freedom. In order to expand on the mutual relationship between education and freedom, I will return once again to Tischner's memories of childhood. From this personal perspective, it is noticeably a period in which freedom is regulated, resulting not only from the demands of family life and obligations imposed by parents and teachers, but very clearly associated with the political and economic system. Tischner grew up in a time during which freedom was constantly threatened, first by 
an occupying power and later by the Communist system and leadership. After the political system changed, the road to freedom also turned out to be problematic and it was no easy task to introduce a legal framework and standards of living and management in a new democratic and liberal state. Among many barriers were those inherent in mentality and the survival strategies that had developed during the regime, which Tischner often referred to and described as homo sovieticus.

Added to this deficit of freedom experienced by Poles and Tischner himself, we can also add another that is related to the private dimension of family life and the child growing up within it. Dependence on one's parents and obligations imposed on children by adults are part of a child's life in which a lack of freedom is experienced. Tischner himself admitted that there were times during his childhood when he ran away from obligations in order to be closer to his passions and interests. It was in a sense, however, a conflict between two different preferences, of a child and an adult, with natural consequences that were destined to follow a lack of compliance with adult instructions. An unjustified (by objective need) order, or an imperative order directed towards a child (usurpation of the adult's will) is an expression of authoritarian education, most often totalist (in other words, one that protects the position of the person worthy of imitation). Growing up in such an atmosphere may be acknowledged as the first encounter with absolute power in the private sphere. We know - also from Tischner's writings - that in this respect Tischner's family life and upbringing was free from absolute power, although the school and seminary environment brought him such examples, which he described, among others, in the text of $Z$ problematyki wychowania chrześcijańskiego. Within the framework of school and the seminary, contact with the totalist teacher is yet another experience of absolute power, still on a prepolitical area (Arendt, 1994, p. 113). Despite this, the path he chose to tread was that of the priesthood, which in those days of absolute Communist rule allowed him, he believed, to maintain his freedom ${ }^{6}$.

On the basis of Tischner's entire thinking on the subject of education as well as freedom, which was presented above, one can distinguish between two types of a lack of freedom; one results from the necessity and shortcomings of nature and the second as pure usurpation of someone's will, often laced with fear and at the same time glorifying and protecting the position of a role model, who gives himself or herself the right to take away the freedom of the other person. Only in the latter case does that lack of freedom

6 Based on the audiovisual material accessible in "Tischnerówka", the House of Memorial for prof. Józef Tischner in Łopuszna. 
fit in clearly with the path from totalitarianism to freedom. In the first case, we are dealing with a lack of freedom that results from a maturing child's participation in his natural environment - family, school and among other persons of faith in the church - within which various justifiable obligations and requirements are imposed.

A lack of freedom experienced by a child that results from assuming responsibilities and tasks assigned by adults should be intertwined with latitude and leave the child space to manage. This free space, influenced by and parallel to the pedagogue's shaping and educational activity, will gradual be transformed into freedom, in a sense developing along with the child, teaching him or her responsibility for undertaken tasks. Tischner rightfully equates freedom with self-management: "liberty is something that a person feels on their own property" . In another dimension, the freedom present on the pedagogical stage is the freedom that characterises a pedagogue from which one can learn. The expression "education through freedom to freedom" accurately captures this dynamic. It includes efforts to learn freedom or to regain it and, conversely, by learning it, we are using it at the same time. By assuming the role of freedom in education, we base and create the entire stage on which actors meet, experiencing and learning freedom.

Tischner, in pointing out the pedagogical errors above all in relation to a Christian education, and thus from an environment he knew well, benefits all pedagogy. Based on the example of Christian pedagogy, he pointed to examples of slavery and fear of freedom that may underlie various totalist claims of pedagogy in general. In Tischner's biography Bonowicz cites an interesting reform postulated by Tischner in reference to the formation of Catholic priests in Poland, dating from 1974, concluding that this work had become the conscience of Polish Christianity long before the events that followed the political change (Bonowicz, 2001, p. 279). The reform in question applied to three aspects of the formation. The first relates to education and should make the church to part ways with negative pedagogy, or the refusal to give any pedagogical credit to those who oppose Catholic doctrine; the second is associated with teaching in the seminary, which is based on discipline and which should be shifted to a focus on internal dialogue, or helping and listening to the human hopes of clerical students; the last dimension involves the "white stains" of Christianity, the distrust of contemporary philosophical currents and trends in culture. Tischner admitted that behind all three aspects requiring improvement was "a basic distrust of the human

\footnotetext{
Quote taken from one of the commemorative plaques at the Parish Church in Łopuszna.
} 
being". Behind this, in turn, is the fear of freedom. Out of this distrust "Christianity without people" is born, when faith in God is espoused by people who have failed themselves (Bonowicz, 2001, p. 279).

\section{Integration of upbringing and instruction on the pedagogical stage}

In practice, a totalist teacher is someone who misrepresents the truth; a totalist pedagogue - Tischner also called such a person hopeless - is a person who takes away hope and betrays the pupil's trust. The teacher plays a leading role in Tischner's pedagogical thinking, so his faithfulness to the principle of speaking the scientific truth stands above all others. This is why a teacher, without detracting from the role of an pedagogue, must give precedence to teaching in accordance with the criteria of truth. This maintains the integration of education, where the primary task of encouraging the student to think is assigned to the teacher and the task of bringing the student to life is given to the pedagogue. A pious attitude is not enough to create a religious education. The doctrinal, philosophical and cultural foundations of a given religion need to be knowledgeably presented without fear of confronting criticism from students living here and now who draw on many cultural sources. The pedagogue is, according to Tischner, secondary to the teacher in the sense that, when inability or a lack of knowledge prevents answering a question or responding to a student's doubts, this lack should be acknowledged, even at the cost of one's position as a role model, the authority that one might want be tempted to use in relation to the student. For Tischner, the first anthropological denominator, according to which we are human beings first, is what counts most; after that - to paraphrase his declaration of being a human being first, a philosopher second and last a priest - one is a teacher and then an pedagogue. "Since a pupil is a free entity - Tischner says - a poor pedagogue is not the horrible tragedy that it might seem to be" (Tischner, 1966, p. 1345). This distinction, sadly, frequently loses in confrontation with specific situations where a poor pedagogue faces a pupil-student who is unaware of this fact or in the feeling of being betrayed by a "toxic" and unreliable pedagogue-teacher. 


\section{The road from slavery to freedom through education -} a summary

Freedom is the name of man - this anthropological principle applied to the pedagogical setting means that this human practice cannot succeed without it. It is, after all, "work with a human being and upon a human being - with a human being who is in the process of maturing" (Tischner, 1984, p. 66). That is why Tischner writes that "education assumes freedom" and "the pupil is a free entity" (Tischner, 1966, p. 1345). The simultaneous collision with totalism in this scene is a sign of pseudos in education. A totalist pedagogue is one of the barriers to freedom, the equivalent of political totalitarianism in a prepolitical area, i.e. in the private sphere of family and within the space of school and church. The first defence against totalism on the pedagogical stage is the teacher's calling to be faithful to the principle of scientific truth, no matter how much it hurts. A student has the right to know and understand. That is why the pedagogical thought of Tischner can be placed within the philosophy of education. The pedagogue's position also defends against totalism, as long as the pedagogue is ready to assume the role of a custodian of the hope students have entrusted. Education is work with another human being, bringing to life and acting in accordance with one's own idea, just like managing your own property; it gives rise to uncertainty, comes with the risk of failure or poor decision-making on the part of the student, but this is also a guarantee of the child's humanistic foundation (renewable hope and faith). It should not be used by any ruling group that wants to "raise more of themselves", or create enthusiasts and supporters of their ideological programme. The road to freedom, therefore, passes through education. It may be a long road, however, if, in addition to absolute political power, the prepolitical areas of home, school or church responsible for education creates only the semblance of pedagogical relationships, while fortifying their positions of pedagogical mechanism, legalism and totalism.

The contribution of Tischner's pedagogical thinking to his philosophy of freedom is considerable. The temptations of total power begin - just like its opposite, freedom - in the sphere of education. Moreover, pedagogical totalism can be maintained independently of absolute political rule, because fear of freedom among citizens is not only characteristic of the world of politics. For centuries it has also been a common attitude in the hierarchies of the Catholic Church. The Second Vatican Council was an important turning point, a new path according to which man has become the way of the church, instead of before, when the church was the way of man. Many of Tischner's descriptions, including both pedagogical texts of the 1960s discussed here, 
declare this shift in thinking as long-awaited, but slowly implemented and resisted by the church community. In both schools and families, with respect to parental and teaching authority, until recently corporal punishment and other methods that harm a child's dignity were used as a pedagogical entitlement within the scope of unquestioned methods to crack down on a lack of compliance with orders or prohibitions laid down by adults for the children in their care. Many of us are also familiar with the scene of an incompetent teacher who compensates for a lack of skill and fear of exposure with ruthlessness, authoritarianism and chilly relations with students. It might be that totalism is still smouldering in the pre-political sphere especially in education, despite the changes taking place in the political sphere to build democratic structures and the rule of law. Pedagogical totalism can be continued independently of political ones and can reinforce it by attitudes of passivity and claims, thus inhibiting the development of civic society in a democratic state. In his pedagogical thinking, Tischner - although he warns against totalist education - trusts at the same time that freedom will be defended, also thanks to wise teachers and pedagogues, who have hope and as free people will want to become custodians of hope for their students and pupils. For many - as well as for me - one of these was Józef Tischner.

\section{Bibliography}

Arendt H. (1994). Między czasem minionym a przyszłym, transl. by M. Godyń, W. Madej. Wydawnictwo Fundacji Aletheia, Warszawa.

Bonowicz W. (2001). Tischner. Wydawnictwo Znak, Kraków.

Filek J. (2001). Filozofia jako etyka. Wydawnictwo Znak, Kraków.

Galarowicz. J. (2013). Ks. Józef Tischner. Petrus, Kraków.

Tischner J. (1966). Z problematyki wychowania chrześcijańskiego. "Znak”, no. 11, p. 1335-1345.

Tischner J. (1968). Z problematyki nauczania. “Znak”, no. 7/8, p. 903-913.

Tischner J. (1984). The Spirit of Solidarity, transl. by M. Zaleski and B. Fiore SJ. Harper \& Publishers, New York-San Francisco.

Tischner J. (1998). Spór o istnienie człowieka. Wydawnictwo Znak, Kraków.

Tischner J. (1999). Przekonać Pana Boga. Z ks. Józefem Tischnerem rozmawiają D. Zańko

i J. Gowin. [To Convince God. Józef Tischner Interviewed by D. Zańko i J. Gowin]. Wydawnictwo Znak, Kraków.

Tischner J. (2000). Świat ludzkiej nadziei. Wydawnictwo Znak, Kraków. 
Tischner J. (2002). Myślenie według wartości. [Thinking in Values]. Wydawnictwo Znak, Kraków.

Tischner J. (2006). Filozofia dramatu. Wydawnictwo Znak, Kraków.

Tischner J. (2008). Spotkanie. Z ks. Tischnerem rozmawia A. Karoń-Ostrowska. Wydawnictwo Znak, Kraków.

Tischner J. (2010). Rozmowy z dziećmi. Kazania niecodzienne. Wydawnictwo Znak, Kraków.

Wajsprych D. (2011). Pedagogia agatologiczna. Studium hermeneutyczno-krytyczne projektu etycznego Józefa Tischnera. Wydawnictwo Naukowe Uniwersytetu Mikołaja Kopernika, Toruń-Olsztyn.

Walczak P. (2007). Wychowanie jako spotkanie. Józefa Tischnera filozofia człowieka jako źródło inspiracji pedagogicznych. Oficyna Wydawnicza "Impuls", Kraków.

Wrońska K. (2010). Człowiek $w$ doświadczeniu wielowymiarowej transcendencji, in: M. Nowak, P. Magier, I. Szewczak (eds.), Antropologiczna pedagogika ogólna. Wydawnictwo KUL and Wydawnictwo GAUDIUM, Lublin, p. 175-188.

Wrońska K. (2018). Wychowanie a wolność. Próba wglądu w myślenie pedagogiczne Józefa Tischnera. "Paedagogia Christiana”, 1 (41), p. 97-115. 